\title{
Hydropower in the Context of Sustainable Energy Supply: A Review of Technologies and Challenges
}

\author{
Chiyembekezo S. Kaunda, ${ }^{1}$ Cuthbert Z. Kimambo, ${ }^{2}$ and Torbjorn K. Nielsen ${ }^{1}$ \\ ${ }^{1}$ Waterpower Laboratory, Department of Energy and Process Engineering, Norwegian University of Science and Technology, \\ 7491 Trondheim, Norway \\ ${ }^{2}$ Department of Mechanical and Industrial Engineering, University of Dar es Salaam, P.O. Box 35091, Dar es Salaam, Tanzania
}

Correspondence should be addressed to Chiyembekezo S. Kaunda, kaundas@gmail.com

Received 7 November 2012; Accepted 3 December 2012

Academic Editors: B. Limmeechokchai, F. E. Little, Z. Oktay, L. Ozgener, and A. Stoppato

Copyright ( 2012 Chiyembekezo S. Kaunda et al. This is an open access article distributed under the Creative Commons Attribution License, which permits unrestricted use, distribution, and reproduction in any medium, provided the original work is properly cited.

Hydropower is an important renewable energy resource worldwide. However, its development is accompanied with environmental and social drawbacks. Issues of degradation of the environment and climate change can negatively impact hydropower generation. A sustainable hydropower project is possible, but needs proper planning and careful system design to manage the challenges. Well-planned hydropower projects can contribute to supply sustainable energy. An up-to-date knowledge is necessary for energy planners, investors, and other stakeholders to make informed decisions concerning hydropower projects. This is basically a review paper. Apart from using expert knowledge, the authors have also consulted extensively from journals, conference papers, reports, and some documents to get secondary information on the subject. The paper has reviewed the world energy scenario and how hydropower fits in as the solution to the global sustainable energy challenge. Issues of hydropower resource availability, technology, environment and climate change have been also discussed. Hydropower is sensitive to the state of environment, and climate change. With global climate change, though globally the potential is stated to slightly increase, some countries will experience a decrease in potential with increased risks. Adaptation measures are required to sustainably generate hydropower. These are also discussed in the paper.

\section{Introduction}

1.1. World Energy Scenario and Sustainable Energy. In this era, concerns about environment and climate change management influence choices investors and international financing institutions make concerning energy projects [1]. The word "environment" can be defined in many ways depending on the discipline; but it is broadly understood to refer to surroundings that interact with life on earth. The surroundings can be divided into nonliving and living components. The important point concerning environment, according to Gorshkov and Makarieva [2], is that it provides resources, such as energy, that support life on earth. Since energy is sourced and processed into a usable form from the environment, activities pertaining to its extraction, transportation, conversion, and utilisation impact the environmental system. The impacts are pronounced in thermal energy systems. For fossil fuel energy systems, it is also not possible to totally avoid emissions and environmental setbacks because of combustion. During the combustion process, energy is converted from chemical into heat and the gaseous products of combustion are ejected from the system at a higher temperature than the ambient (as dictated by Second Law of Thermodynamics). Some of the gaseous products of combustion are harmful to life and climate system, as will be discussed later in the paper.

The increase in global energy demand as a result of population and economic growth in developing countries coupled with huge demand from developed countries is well documented. According to the statistics from International Energy Agency (IEA), the documented values show that the total global primary energy supply in 2009 was 12,150 Mtoe up from 6,111 Mtoe in 1973 [3], indicating an almost 100\% increase. The global energy supply is still dominated by fossil 
TABle 1: Data on fossil fuel types and their global consumption levels, amount of their proven reserves, and amount of lifetime reserves basing on their 2006 consumption rates, adapted from InterAcademy Council [6].

\begin{tabular}{|c|c|c|c|c|c|c|c|c|c|}
\hline \multirow{2}{*}{ 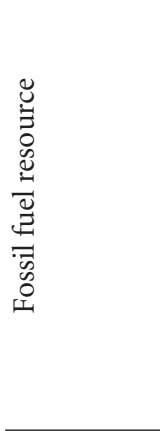 } & \multicolumn{4}{|c|}{ Consumption (EJ) } & \multirow{2}{*}{ 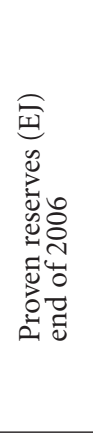 } & \multirow{2}{*}{ 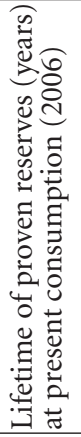 } & \multirow{2}{*}{ 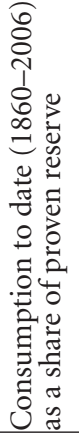 } & \multirow{2}{*}{ 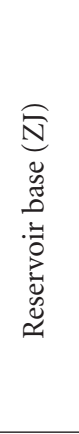 } & \multirow{2}{*}{ 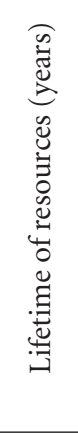 } \\
\hline & 1860-1998 & 1999-2006 & 2006 & 1860-2006 & & & & & \\
\hline Oil & 5,141 & 1,239 & 164 & 6,380 & 6,888 & 42 & $93 \%$ & 32.4 & 198 \\
\hline Natural gas & 2,377 & 785 & 109 & 3,163 & 7,014 & 64 & $45 \%$ & 49.8 & 461 \\
\hline Coal & 5,989 & 878 & 130 & 6,867 & 19,404 & 149 & $35 \%$ & 199.7 & 1,538 \\
\hline
\end{tabular}

EJ: Exajoule $=10^{18} \mathrm{~J}$; ZJ: Zettajoule $=10^{21}$ Joule $=10^{3} \mathrm{EJ}$.

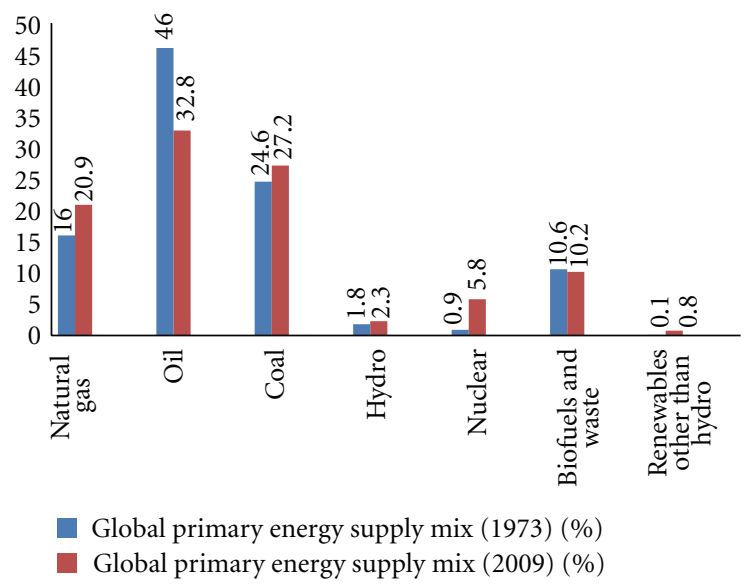

FIGURE 1: Global primary energy supply mixes in 1973 and 2009, adapted from International Energy Agency [3].

fuel (coal, natural gas, and oil): fossil fuel contributes around $80 \%$ of the 2009 total mix as compared to about $87 \%$ in 1973 (refer to Figure 1). The contribution from other fuel sources is quite minimal. The mix from biofuels and waste (about 10\%) is basically derived from biomass solid-fuel sources mainly for provision of domestic thermal energy requirements [4]; a predominant source of energy in less developed regions of the world such as sub-Saharan Africa.

The energy review study by the British Petroleum shows that in 2011, the global primary energy consumption grew by $2.5 \%$; natural gas consumption grew by $2.2 \%$; and oil consumption grew by $0.7 \%$. Coal alone growth by $5.4 \%$ and was noted as the fossil fuel to grow above the global average [5]. Coal in 2011 was accounted for $30.3 \%$ of global energy consumption and was quoted as having the highest share since 1969 [5]. Considering the environmental consequences of fossil fuel energy systems, the global overdependency on fossil fuels paints a gloomy picture on the earth's environmental system. Further, the overdependency on fossil fuels exerts pressure on the limited energy resources which may seriously affect global economy in the future due to shortage.

Therefore, it is important to ensure that energy is extracted, converted, and utilised sustainably. The term "sustainable energy" is most of the time applied when one wants to describe energy that is not associated with significant environmental damage (and climate change) and whose current generation does not compromise on the potential of future generations to meet their energy needs. The transition to sustainable energy resources provides an opportunity to address multiple environmental, economic, and development needs of the country and the world at large $[6,7]$.

Currently, one of the issues confronting the world is the challenge of achieving a truly sustainable energy system [8]. The present path of economic development in most of the industrialised and emerging countries overrelies on energy from fossil fuel. Review of global fossil-fuel resources indicates that proven reserves for these resources are still abundant and are able to continue supporting the economy for the next several decades, as can be seen from Table 1 [6]. Coal reserves are more abundant than oil and natural gas. At the rate of 2006 coal consumption, present coal reserves are adequate to support another approximate 150 years [6]. For oil and natural gas, the present reserves can support consumption of up to 40-65 years [6]. Despite the fact that new reserves of fossil fuels are being discovered in many countries and extraction capabilities are being improved, the key message from this paper is that these resources are finite and, therefore, at some time in future they will be depleted.

The facts that currently fossil fuels dominate the global energy system and that there are still some decades to come for these resources to get depleted stress the need to put in place measures to ensure that energy is generated sustainably. Some of these measures are finding alternatives for oil in the transport sector, using low carbon technologies for generating electricity and embarking on energy efficiency programs. 
It must also be stated that, geographically, fossil fuel resources are not evenly distributed. Nations without fossil fuels and capabilities to refine them depend on imports. The volatility in international energy prices for the fossil fuel and the need to secure foreign currency to import the fuel, especially oil, can exert national economic challenges that sometimes can contribute towards economic meltdown. As stated already, these fossil fuel resources are getting depleted while the demand is increasing; thus, it can be expected that prices will be higher in the future than it is currently due to shortage of supply. The volatility in price can be exacerbated by political/civil conflicts experienced in some regions/countries that are endowed with fossil fuel resources. The conflicts can disrupt fuel production and supply. To describe a situation of likelihood that a nation will, at any time in future, access the right amount and form of energy at affordable price, a term "energy security" is used.

Energy security is one of the drivers for sustainable energy system because it calls for an expansion, diversification and localisation of energy sources. The other drivers for sustainable energy include the call for increased access to modern forms of energy especially in the least developed countries to foster development and curb natural resource degradation. This paper discusses hydropower as one of the important renewable energy resources for generating electricity and hydropower's global position in sustainable energy generation. Before such a discussion on hydropower, issues of global environment and climate change are briefly discussed because they are argued as the main concerns for energy systems, as stated earlier.

\subsection{Environmental Degradation, Climate Change, and Energy.} Environmental degradation and climate change are stated to be among some of the challenges facing the world today $[9,10]$. Despite the fact that there are some natural processes causing environmental and climatic deviations, current research indicates that these processes are insignificant compared to the human-induced processes [11]. Processes such as those concerning unsustainable energy extraction, conversion, and utilisation have contributed to the worsening of these global changes. Environmental degradation and increase in global average temperature have altered the natural way the earth regulates its atmospheric air composition and temperature thereby weakening the earth's self-climate regulating system.

Climate change is defined in many ways. According to Intergovernmental Panel on Climate Change (IPCC) [12], "climate change refers to any change in climate system over time which can be identified (e.g., using statistical tests), whether due to natural variability or as a result of human activity." United Nations Framework Convention on Climate Change-UNFCCC defines climate change as "a change of climate which is attributed directly or indirectly to human activity that alters the composition of the global atmosphere and which is in addition to natural climate variability observed over comparable time periods" [13]. According to Young Europeans Discuss Sustainable Development [14], "Climate change is a long-term change in the statistical distribution of weather patterns over periods of time that range from decades to millions of years. It may be a change in the average weather conditions or a change in the distribution of weather events with respect to an average period of time." Therefore, from these definitions, when answering the question of climate change in a country or region through research, both natural and human-induced weather changes in climate system have to be analysed over a relatively long period of time (several decades or century). The main cause of climate change is the global warming as a result of humaninduced gases (or emissions) that trap heat from solar energy in the atmosphere in the same way a "greenhouse" does. They are also known as Greenhouse Gases (GHGs). Carbon dioxide is the major greenhouse gas; others are methane, nitrous oxide, and carbon-fluorinated gases [15].

All GHGs have different capacities of trapping heat (global warming potential) but when it comes to analysing their potentials, these GHGs are weighted relative to the global warming potential of carbon dioxide. IPCC states that global GHG emissions levels have grown since preindustrial times, with an increase of 70\% between 1970 and 2004 [16]. The IPCC further states that the largest growth in global GHG emissions between 1970 and 2004 had come from the energy supply sector that is dominated by fossil fuels. The other sectors that contributed with significant shares of GHG are the transport, industry and land use, land use change, and forestry (LULUCF) [16]. With the current development practices, IPCC states that global GHG emissions will continue to grow over the next decades [16]. Some recent studies agree with IPCC projections. For example, a study on trends in the global $\mathrm{CO}_{2}$ emission supported by The Netherlands Environmental Assessment Agency and Joint Research Centre of the European Commission states that the $\mathrm{CO}_{2}$ emissions increased by $3 \%$ in 2011. This increase is above the past decade's average annual increase of $2.7 \%$ [17]. In 2011, around 35 billion $\mathrm{CO}_{2}$ equivalent was emitted globally and the top emitters are China (29\%), the United States (16\%), the European Union (11\%), India (6\%), the Russian Federation (5\%), and Japan (4\%) [17]. Some scientific studies conclude that avoiding the most severe changes in the climate system will require keeping the average global warming to not more than $2^{\circ} \mathrm{C}$ relative to preindustrial levels [18].

The human response to challenges of global climate change is basically twofold: to reduce greenhouse gas emissions into the atmosphere (mitigation) and to adapt to the impacts of climate change (adaptation). In this regard, in 1997, several countries signed a treaty known as Kyoto Protocol. The treaty legally mandates developed nations to limit greenhouse gas emissions according to the set targets. The protocol mandates Annex-I countries (developed nations who are signatory to the protocol) to reduce their GHG emissions by about $5 \%$ from their 1990 levels in the first commitment period. These nations can attain their emission reduction targets elsewhere by investing or buying carbon credits from a project that has been proven to reduce greenhouse gases, through the Clean Development Mechanism (CDM). The Kyoto Protocol's first commitment period started in 2008 and ends in 2012, the second commitment period commences in 2013 [13]. Developing countries are not mandated 


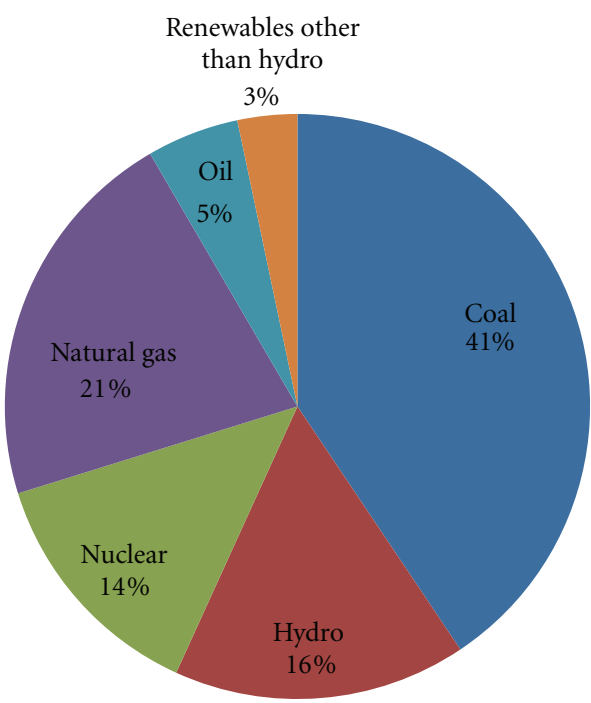

Figure 2: Fuel shares of global electricity generation in 2009, adapted from International Energy Agency [3].

to reduce emissions; however, they are encouraged to do so, so that they can participate in the fight against the global climate change as well as sustainable development [13].

Greenhouse gas emissions from the energy sector account for about $70 \%$ of the total GHG emissions and electricity generation account for a bigger share of global energy consumption [19]. The fossil fuels are still the dominant source of energy for electricity generation; in 2009 they contributed to about two-thirds $(67 \%)$ of the total global electricity generation capacity of about 20,000 TWh; with coal alone contributing about $40 \%$ of the capacity [3], refer to Figure 2. Fossil fuel, especially coal, remains the largest source of electricity generation in the near future, considering the fact that the current proven coal reserve is able to take more than a century to get depleted, as stated before.

Because most of the GHGs are contributed from the energy and land-use sectors, most of the climate change mitigations measures are geared at reducing emissions from the energy sector and enhancing the capacity of carbon sinks in the forests [11]. This is where development of clean energy sources such as renewables is needed so as to reduce the GHG emissions. Fossil fuel substitution to renewable energy sources has high potential to mitigate climate change because they are associated with very little GHG emission levels. According to [4], the median values for all renewable energy lifecycle emissions are reported to range from 4 to $46 \mathrm{~g} \mathrm{CO}_{2} \mathrm{eq} / \mathrm{kWh}$, while those for fossil fuels range from 469 to $1,001 \mathrm{~g} \mathrm{CO}_{2} \mathrm{eq} / \mathrm{kWh}$. The lifecycle emissions from renewable energy are mainly from the process of component manufacturing and system installation of renewable energy generation plants. Renewable energy is defined as any form of energy from solar, geophysical, or biological sources that is replenished by natural processes at a rate that equals or exceeds its rate of use [20]; therefore, it can play a key role in ensuring national energy security. Renewable energy sources have the potential to provide energy to meet or exceed the global energy requirements [21]. Further, because renewable energy is generally associated with nil or minimal gaseous emissions to cause damage to the atmospheric air composition, its importance is not only in climate change mitigation but also in air pollution control.

Developing countries such as those found in sub-Saharan African (SSA) region are well positioned for the application of renewable energy systems because of the relatively huge demand of sustainable energy for development. Renewable energy supply in the form of electricity and heat may help in alleviating the problems of serious electricity shortage and region's overdependence on traditional biomass [22]. In developed and emerging countries, renewable energy can help end the present relationship that correlates economic development with carbon emission. Further, investments in renewable energy technologies can help create jobs and attract extra income from international carbon trading schemes such as the CDM.

The next section of the paper discusses hydropower as one of the most important renewable energy sources, especially in electricity generation. Issues of hydropower technology, global potential, GHG emissions from hydropower projects, environmental consequences of a hydropower project, environment degradation, and climate change impacts on hydropower generation are discussed. A way forward in terms of technology improvements and other adaptations measures against environmental/climate change challenges is also discussed. Small hydropower plants, enjoying the "small is beautiful" as a solution of reducing environmental impacts of large-scale hydropower projects, are also discussed.

\section{Hydropower Generation: Technology, Environment, and Climate Change Perspective}

2.1. Hydropower Technology. In engineering, power is the rate with respect to time of doing work. The work may be in form of mechanical, electrical, or hydraulic. In any work process, forces are involved on or by a system whereby a system is defined as a quantity of matter that is bounded. Hydropower is the rate at which hydraulic energy is extracted from a specific amount of falling water as a result of its velocity or position or both. The rate of change of angular momentum of falling water or its pressure or both on the turbine blade surfaces creates a differential force on the turbine runner thereby causing rotary motion. As a working fluid, water in a hydropower system is not consumed, it is thus available for other uses.

Hydropower can be used to power machinery or to generate electricity or both at the same time. The mechanical application is mainly true for small-scale hydropower plants where the power generated is used to power small-scale mechanical tools and machines for pressing, milling, grinding, and sawing applications. In some instances, the output shaft from the small-scale hydropower turbine is extended in both directions to provide space for both mechanical power provision and electricity generation. 


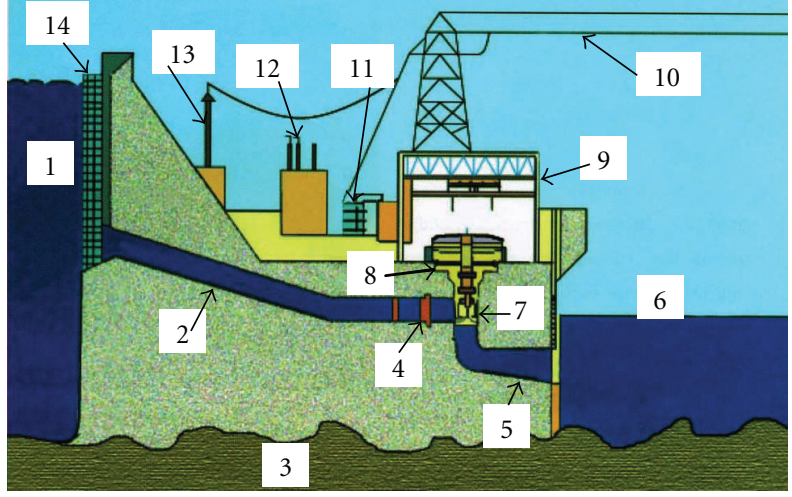
(1) Reservoir
(6) Tailrace water
(2) Penstock
(7) Turbine
(3) Bed rock
(8) Generator
(4) Valve
(9) Power house
(11) Transformer
(12) Insulators
(13) Transmission tower
(5) Draft tube
(10) Transmission lines

Figure 3: Schematic view of a hydropower station and its basic parts, adapted from International Energy Agency [32].

Large-scale hydropower plants are normally used for electricity generation. The basic schematic diagram for hydroelectric power generation system is shown in Figure 3. To produce electricity, the turbine output shaft is coupled to the generator. The generator is principally made up of electromagnetic rotor that is located inside a cylinder (known as stator) containing a winding of electric wires (known as conductor). During operation, the rotor in the stator turns and generates electricity by the principle of electromagnetic induction. The generated electricity is transmitted to load points through a transmission system that consists of components such as switch yard, transformers, and transmission lines.

For a well-planned and -operated hydropower project, hydropower electricity generation technology is stated as one of the cheapest in terms of electricity generation costs [33], possibly because the fuel (falling water) is available without direct costs associated with fuel purchase. The levelised cost of electricity generation for large-scale projects ranges from $0.02 \mathrm{US} \$ / \mathrm{kWh}$ to $0.19 \mathrm{US} \$ / \mathrm{kWh}$ [34]. The relatively low electricity generation cost may be one of the reasons why hydroelectricity is recommended as base load for most of the power utility companies.

Hydroelectric power plants are able to respond to power demand fluctuations much faster than other electricity generation systems such as thermal electric power stations $[35,36]$. This makes hydropower a flexible energy conversion technology and also explains why hydroelectric power stations are sometimes used for peaking purposes. Further, hydroelectric power technology is a high efficient energy conversion process because it converts directly mechanical work into electricity, both of which are high forms of energy. The energy conversion system efficiency for a well-operated hydroelectric power plant can be around $85 \%$, while the system efficiencies for thermal-electric plants are less than $50 \%$ [37].
TABLE 2: Small-scale hydropower classification by installed capacity (MW) as defined by various countries and organizations.

\begin{tabular}{lcc}
\hline Country/organization & $\begin{array}{c}\text { Small-scale } \\
\text { hydropower as defined } \\
\text { by installed capacity } \\
\text { (MW) }\end{array}$ & $\begin{array}{c}\text { Source of } \\
\text { reference }\end{array}$ \\
\hline Brazil & $\leq 30$ & {$[23]$} \\
Canada & $\leq 50$ & {$[23]$} \\
China & $\leq 50$ & {$[24]$} \\
India & $\leq 25$ & {$[25]$} \\
France & $\leq 10$ & {$[23]$} \\
USA & $\leq 30$ & {$[26]$} \\
Norway & $\leq 10$ & {$[27]$} \\
Sweden & $\leq 1.5$ & {$[28]$} \\
South Africa & $\leq 10$ & {$[29]$} \\
ESHA, Portugal, Spain, & $\leq 10$ & {$[28]$} \\
Ireland, Greece, Belgium & $\leq 20$ & {$[28]$} \\
United Kingdom & $\leq 10$ & {$[30]$} \\
International Energy Agency & $\leq 10$ & {$[31]$} \\
World Commission on Dams & &
\end{tabular}

2.2. Classification of Hydropower Projects. Hydropower projects are unique, in the sense that the installations, though having the same installed capacity, may not be identical because the design of hydropower plant is site-specific. This uniqueness of hydropower projects makes their classification important especially in matters concerning technology and application. Hydropower projects (or schemes) are usually classified according to size, head, and whether water for power generation is significantly impounded or not.

Hydropower classification according to size has led to projects being classified as small-scale and large-scale hydropower systems, based on the level of the installed electricity capacity. Various countries or groups of countries and organizations define hydropower schemes based on size differently, as can be seen in Table 2. Many countries, especially in Europe, consider $10 \mathrm{MW}$ as the limits for small hydropower, and above this limit, the hydropower system is considered a large-scale project. The classification based on installed electrical capacity is important because of its being used in legal documents (such as rural electrification acts and power supply contracts agreements). This difference in categorization has created a debate on the size of hydropower system to be considered on the CDM as a small hydropower system [38].

A classification by head refers to a difference in level between inlet (headrace) and outlet (tailrace) of a hydropower installation. Head is one of the important parameters in the design because it determines the water pressure (hence the force) acting on the turbines and hence power output. There is again no consensus concerning classification of hydropower projects according to head. For example, according to European Small Hydropower Association [28], hydropower projects are classified according to the "head" as follows-high head: $100 \mathrm{~m}$, and above; medium head: 30-100 m; and low head: 2-30 m. In India, a high head 


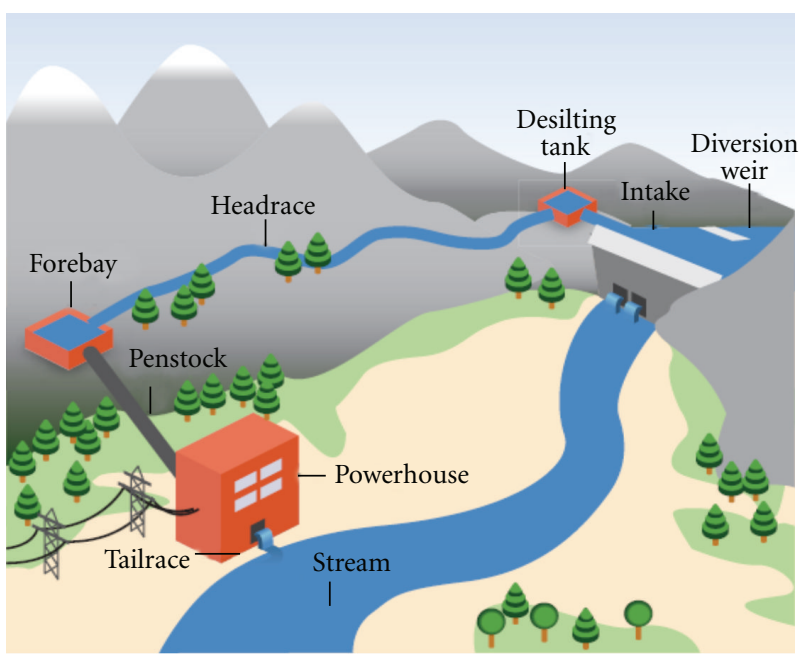

FIGURE 4: Schematic diagram of a typical run-of-river hydropower system [4].

hydropower project is above $40 \mathrm{~m}$, low head one is less than $40 \mathrm{~m}$, and ultralow is less than $3 \mathrm{~m} \mathrm{[39].}$

When categorizing hydropower basing on levels of water impoundment, there are three main types of projects namely: run-of-river, reservoir (storage hydro) and pumped storage. These types are described in the following subsections.

2.2.1. Run-of-River Type. A run-of-river hydropower project (RoR HP), as shown schematically in Figure 4, generates electricity from the river flow without significant impoundment. Water flow in the river depends on precipitation, groundwater flow and runoff: these parameters may have substantial daily, monthly, or seasonal variations. Therefore, ideally for a variable flow river, a RoR hydropower system will have a variable power generation that mimics the river flow profile. To ensure some limited degree of adaptation to the electricity demand profile, the RoR HP includes some short-term storage (known as pondage), to provide extra electricity demand (limited peak demand) when required. Without significant storage system, RoR HP schemes are vulnerable to changes in the river system that affect amount of flow and its water quality, for example, droughts, floods, and water abstractions.

RoR HP scheme is stated to be suitable for a river that has minimum flow variation or a river that is regulated by a large natural reservoir (e.g., a lake) [40]. The RoR HP projects are not associated with a lot of construction activities, and because of this, RoR HP projects possess economic as well as environmental advantages over other hydroelectricity generating systems of the same installed capacity $[41,42]$. RoR hydropower generation technology is used in many countries of the world. For example, in Malawi, almost all of the hydropower electricity generation projects are RoR HP plants cascaded along the Shire River, an outlet from Lake Malawi [43]. In Canada, in the Province of British Columbia, in 2006, $64 \%$ of the independent electric power production was sourced from RoR HP plants contributing to

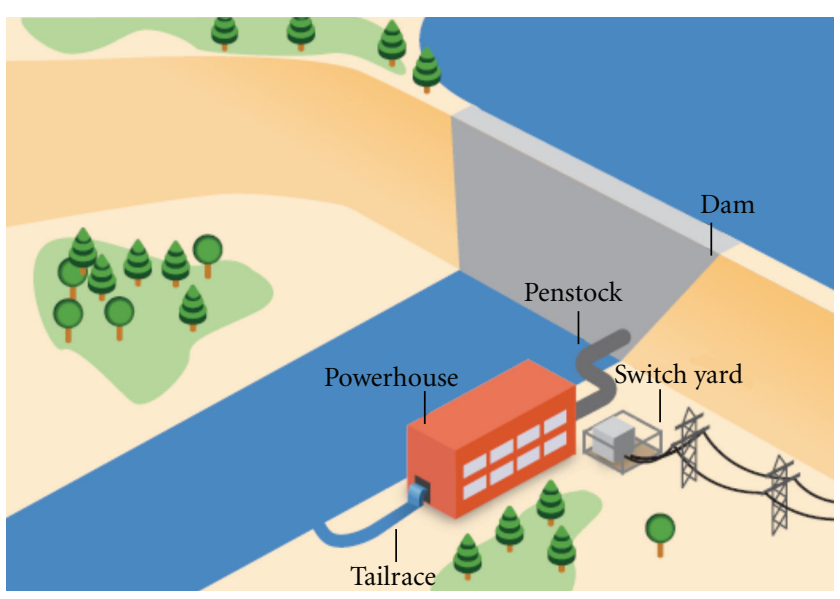

FIGURE 5: Schematic diagram of a typical hydropower plant with reservoir [4].

about $27 \%$ of the total electricity generation [42]. Further, because of their economic advantage, RoR HP plants are the commonly used in small-scale hydropower systems [43].

Run-of-river hydropower plants can be divided into two different types, according to how the flow diversion system is arranged. The diversion system can be either of in-stream or cross-watershed. In-stream diversion system, which is quite common in RoR HP projects (refer to Figure 4), diverts a portion of water from the river bed to take advantage of the local topography so as to have an improved head. This is to optimize hydropower generation from the site. In large-scale hydropower projects, the diverted portion of the river may be dammed and diverted through tunnels in the mountain side to the powerhouse and then discharged further downstream back in its riverbed [32]. In cross-watershed diversion, the aim is to increase volume of water flow in the river where the power plant is located. Flow from another river is diverted across the catchment area into the river where the power plant is located. The increased flow in the river will again improve the energy generation [32]. It is possible to combine the two diversion systems to optimise energy generation on the site. The most widely used scheme for in-stream RoR HP plant consists of an open channel, a forebay, and a generally relatively short penstock [41].

\subsubsection{Storage Hydropower. A storage hydropower project has} a reservoir behind a dam to store water for later power generation (and other purposes), as shown schematically in Figure 5. The reservoir regulates the flow and, thus, storage hydropower plants have more power reliability than RoR HP plants. The generating stations may be located just at the dam toe or further downstream connected to the reservoir through tunnels or pipelines.

Storage HP projects are typically used for highly variable flows in the middle reaches of a river system [32]. The opportunities offered by the topography influence the design and type of reservoir that can be constructed on the river. Storage HP schemes constructed on gorges and canyons are associated with high output and efficiency [32]. 


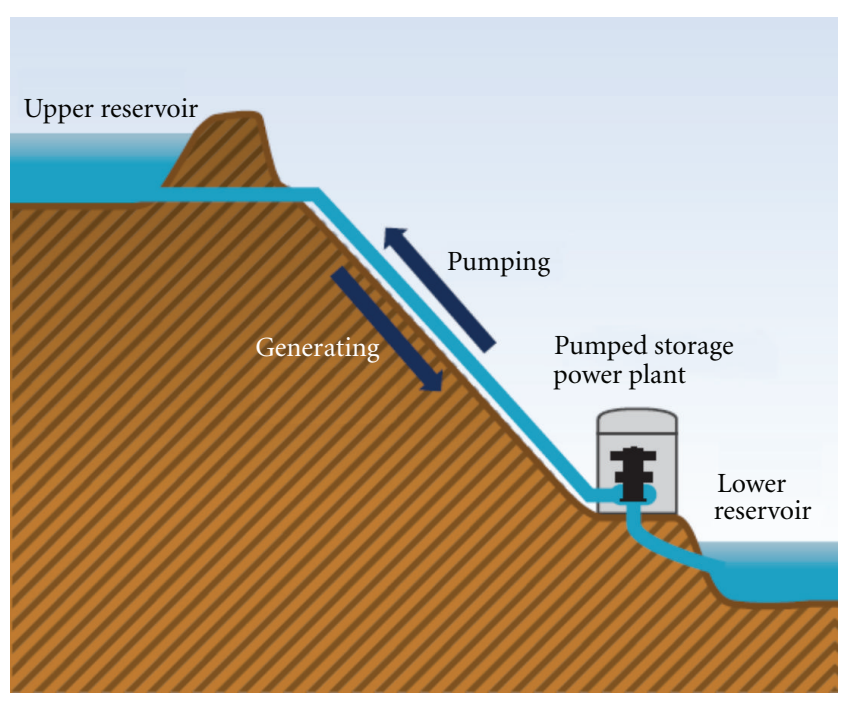

FIGURE 6: Schematic diagram of a typical pumped storage system [4].

Storage hydropower schemes are superior in terms of offering energy benefits as compared to pure run-of-river schemes. One of the fundamental advantages of storage hydropower is the storage of energy in form of potential energy in water behind a dam. This potential energy can be released to generate hydroelectricity when needed and, thus, the storage hydropower system can be used for supplying both base load and peaking load. Beside the advantage of energy storage, storage hydropower projects have the ability to regulate flow in the river downstream of the dam. In this case, a reservoir may increase the reliability of power generation from the sites located downstream, as the regulated river will typically flow more evenly throughout the year. Thus, multiple run-of-river power plants may be installed downstream in cascade form, using the same water to produce additional hydropower of constant output. Further, because of regulated flow into the powerhouse, control of power and efficiency of generation for a storage hydropower system is enhanced. Efficient but flow-sensitive turbines like Kaplan and Francis are able to be operated at best efficiency point with a high degree of performance reliability.

2.2.3. Pumped Storage. Pumped storage plants, shown schematically in Figure 6, are not energy sources, but are simply hydraulic energy storage devices [44]. Practically, in terms of both design and economics, pumped storage technology is stated to be the only large form of grid-based electric energy storage currently available to the power utility $[45,46]$. In pumped storage system, water is given hydraulic energy by a pump. Water is pumped from a lower reservoir into an upper reservoir, using excess electricity generated by the hydropower plant during off-peak hours or at any other times when demand is reduced. During the peak load times or at other times when extra electricity is needed, extra electricity is generated from water stored in the upper reservoir as it is released back to the lower reservoir via a turbine. It is possible to employ a turbomachine that can be operated both as a pump and a turbine in this case, for example, a reversible pump-turbine machine like a Reversible Francis Turbine.

The lower reservoir can be a river, a lake or an existing reservoir (for hydropower generation or other purposes) and ideally, any electric generating station can use pumped storage technology. Although the energy losses incurred during the pumping process make the pumped storage a net energy consumer, the system is able to provide large-scale energy storage with flexibility at low operating costs [32]. For a hydropower system incorporating pumped storage technology, the point of concern is the high investment cost relative to other hydropower generating systems of the same installed capacity. The pumped storage technology installation requires special sites. Mountainous areas are ideal for the technology in order to make use of the topography for potential energy storage. The distance between the reservoirs also matters in the design of the pumped storage because long distances increase the investment costs and the pumping losses; making the system unattractive economically and technically. The pumped storage technology is not only ideal in managing peak power demands, but it also ensures that process of governing the electricity production is efficient. The latter advantage comes about because the hydropower plant with pumped storage generates electricity at nearly constant output, thus fixing load available on the generators. This condition is necessary for a smooth governing process.

\subsection{Hydropower as a Renewable Energy and Its Global} Resource Potential and Generation. Hydraulic energy in the water is derived from a hydrological cycle as shown in Figure 7. In the hydrological cycle, water constantly flows through a cycle in different phases; evaporating from lakes and oceans, forming clouds, precipitating as rain or snow, then flowing back down to the ocean, seas, dams, rivers, and other water bodies. The main source of energy driving the hydrological cycle is solar and it is estimated that about $50 \%$ of all solar radiation reaching the earth is used to evaporate water in the cycle [4]. Because the hydrological cycle is an endless process, hydropower is considered as a renewable energy resource, according to the definition. Due to engineering reasons concerning the integrity of properties of materials for constructing hydroelectric power plants, only freshwater resources are used to generate hydropower. The main characteristics of hydropower potential are flow $(Q)$ and head $(H)$, as given by the following power equation:

$$
P_{\text {hydro }}=C_{p} H Q \text {, }
$$

where $C_{p}$ is the hydropower coefficient, a constant.

As can be seen from hydropower equation (1), in practical sense, the flow parameter is the only variable since the head cannot be increased or improved upon at least for most of hydropower projects. The flow for hydropower generation can be regulated, thereby controlling power production. In some instances head can be modified, for example, by means of pumping water from other source(s) into 


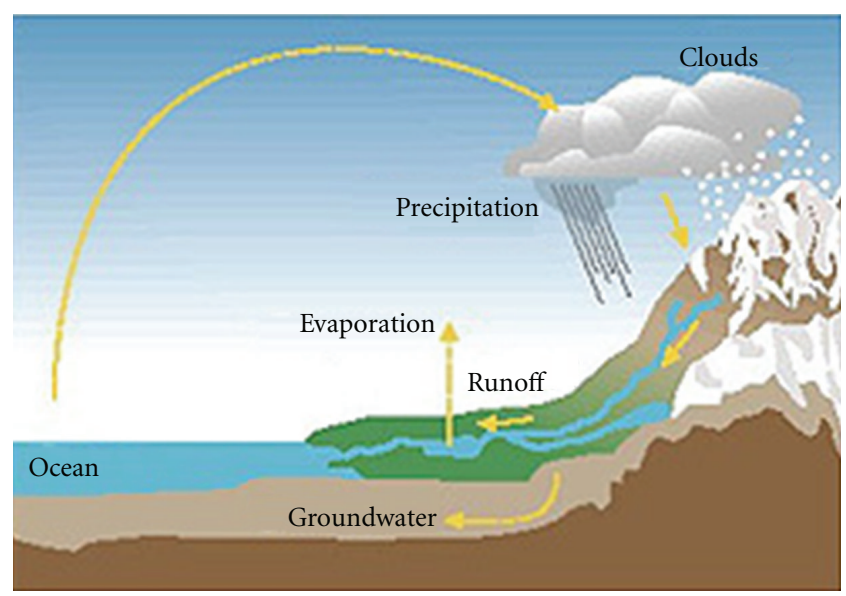

Figure 7: Hydrological cycle [48].

a reservoir or regulating the water entrance and exit from the reservoir. Hydropower plants utilizing flow and head as given in (1) are called conventional hydropower systems. The unconventional hydropower systems use only the kinetic energy in the water current to drive the turbine and generate power. These systems are usually installed in-stream to the waterways such as high velocity rivers, irrigation canals, and water supply systems. The unconventional hydropower systems are also known as zero-head hydropower systems or hydrokinetic power systems.

Hydropower is stated to be the largest renewable energy resource in the world; in 2009 it produced 3,329 TWh of electricity representing a share around $16.5 \%$ of the world's electricity $[3,35]$. It is the one of the most important source of power in many countries: according to World Energy Council 2010 Report, about 160 countries in the world have hydropower in their national electricity generation mixes [47]. However, the actual global production of hydropower is concentrated in the top ten countries (contributing around $70 \%$ of the total electricity production) [47]. The first top four countries, namely, China, Brazil, Canada, and USA, contribute with about half of the total electricity production, as shown in Table 3.

Despite being used in many countries, hydropower contributes significantly less towards the worldwide total primary energy supply: in 2009, it contributed only $2.3 \%$ of the total 12,150 Mtoe primary energy supply worldwide [3]. Despite contributing relatively less to the world energy mix, the average global potential is stated to be relatively huge; in 2009, the World Commission on Dams estimated that the total worldwide proven technical potential for conventional hydropower was $14,576 \mathrm{TWh} / \mathrm{yr}$ [49], as seen in Table 4. If the hydropower potential from small-scale hydropower sites and from nonconventional sources are taken into account, then the world hydropower potential is very large considering numerous availability of small hydropower potential sites in many countries and potential of water current in rivers and canals (such as water supply and irrigation canals). From Figure 8(a) (constructed from Table 4), it can be seen that Asia has the largest share (over
TABle 3: Electricity Production and share of world electricity production in top ten countries and the rest of the world in 2010, adapted from World Energy Council [47].

\begin{tabular}{lcc}
\hline Country & $\begin{array}{c}\text { Electricity production } \\
(\text { TWh })\end{array}$ & $\begin{array}{c}\text { Share of the world total } \\
\text { electricity production } \\
(\%)\end{array}$ \\
\hline China & 616 & 18.5 \\
Brazil & 391 & 11.7 \\
Canada & 364 & 10.9 \\
USA & 298 & 9 \\
Russia & 176 & 5.3 \\
Norway & 127 & 3.8 \\
India & 107 & 3.2 \\
Venezuela & 90 & 2.7 \\
Japan & 82 & 2.5 \\
Sweden & 66 & 2 \\
Rest of the world & 1012 & 30.4 \\
World & 3,329 & 100 \\
\hline
\end{tabular}

$53 \%$ ) of hydropower global potential, followed by Latin America (20\%) and North America (11\%). Again, Asia has a large share $(43 \%)$ of the worldwide installed capacity. It is worth noting from Figure 8(b) that Africa, despite having almost the same technical potential (installed capacity) with Europe, the latter has a larger share (19\%) of the total worldwide installed capacity than the former (only 3\%). It is also important to note from Table 4 that large share of the world's proven technical generation potential is still undeveloped (76\%); Africa has the most undeveloped potential (92\%) followed by Asia and Australasia/Oceania (80\% for both regions). Therefore, technically, with such a large share of undeveloped potential, hydropower fits very well in the context of providing sustainable electricity for development in Africa-the region of the world where electricity is needed most. Challenges associated with lack of financing in other regions of the world such as Africa are stated to be some of the main reasons for the underdevelopment of hydropower in such regions [47].

The average regional hydropower capacity factor varies: it ranges from $32 \%$ in Australasia/Oceania to $54 \%$ in Latin America. Capacity factor is the amount of actual electricity energy generated by a power station for a specified period of time (e.g., a year) over the electricity the power station would have generated in the same period if the power was being generated at the ideal power rating (nameplate rating on the generator). For a hydropower system, capacity factor depends not only on the availability of water for power generation, but also on whether the power station is designed as a peaking or base load plant. A peaking plant has low capacity factor because the plant operates only during specific times while a base-load has a high capacity factor because the plant operates most of the times. Further, a hydropower station may not have a $100 \%$ capacity factor even if enough water is available because of the intentional curtailment of power generation due to (i) plant shutdown for routine maintenance, (ii) as a response to reduced 
TABLE 4: Regional hydropower generation potential, installed capacity, undeveloped potential, and capacity factor in 2009, adapted from World Commission on Dams [49].

\begin{tabular}{|c|c|c|c|c|c|c|}
\hline World region & $\begin{array}{c}\text { Technical } \\
\text { potential-annual } \\
\text { generation }(\mathrm{TWh} / \mathrm{yr})\end{array}$ & $\begin{array}{c}\text { Technical } \\
\text { potential-installed } \\
\text { capacity }(\mathrm{GW})\end{array}$ & $\begin{array}{l}2009, \text { Total } \\
\text { generation } \\
(\mathrm{TWh} / \mathrm{yr})\end{array}$ & $\begin{array}{l}2009, \text { installed } \\
\text { capacity (GW) }\end{array}$ & $\begin{array}{l}\text { Undeveloped } \\
\text { potential (\%) }\end{array}$ & $\begin{array}{c}\text { Average regional } \\
\text { capacity factor } \\
(\%)\end{array}$ \\
\hline North America & 1,659 & 388 & 628 & 153 & 62 & 47 \\
\hline Latin America & 2,856 & 608 & 732 & 156 & 74 & 54 \\
\hline Europe & 1,021 & 338 & 542 & 179 & 47 & 35 \\
\hline Africa & 1,174 & 283 & 98 & 23 & 92 & 47 \\
\hline Asia & 7,681 & 2,037 & 1,514 & 402 & 80 & 43 \\
\hline Australasia/Oceania & 185 & 67 & 37 & 13 & 80 & 32 \\
\hline World & 14,576 & 3,721 & 3,551 & 926 & 76 & 44 \\
\hline
\end{tabular}

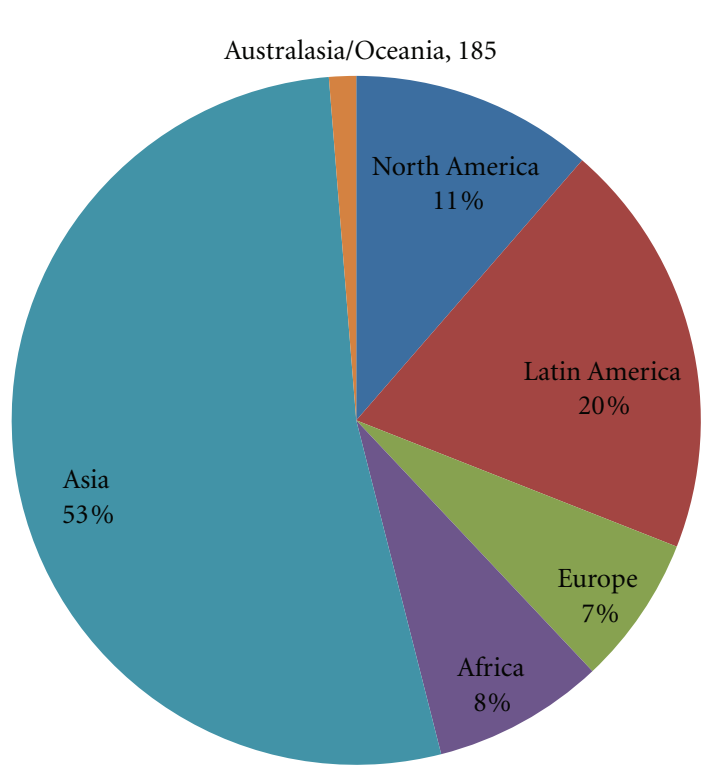

(a)

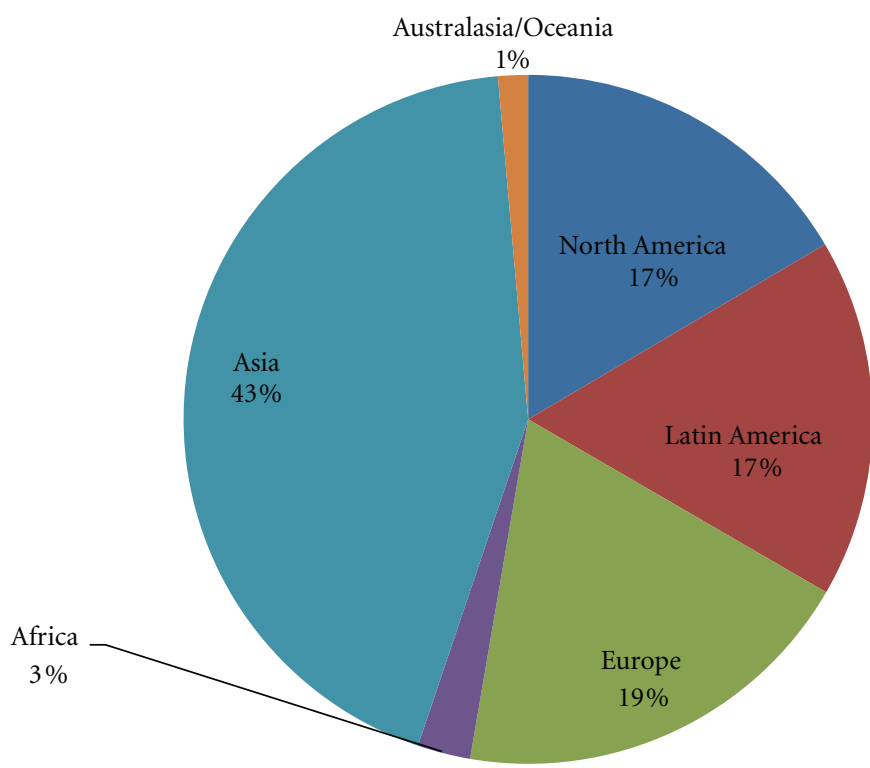

(b)

FIGURE 8: (a) Share of world hydropower technical generation potentail by region in 2009, adapted from World Commission on Dams [49]. (b) Share of world hydropower installed capacity by region in 2009, adapted from World Commission on Dams [49].

electricity demand, and (iii), in other cases, to respond to the reduced price of electricity for economical generation. From Table 4, the worldwide average capacity factor for hydropower is $44 \%$.

The worldwide total installed hydropower capacity in 2009 was to be $926 \mathrm{GW}$ by World Energy Council [47] and $956 \mathrm{GW}$ by the International Energy Agency [3]. A conservative figure of $860 \mathrm{GW}$ was proposed by International Hydropower Association [50] as a fair reflection of the situation. The worldwide-installed capacity did not include pumped storage installations which were estimated to be around $120 \mathrm{GW}$ and $150 \mathrm{GW}$ [50]. The World Energy Commission estimated that in 2009, the amount of worldwide total hydropower electricity generation was around $3,550 \mathrm{TWh} / \mathrm{yr}$ [47]. If the annual generation is compared with the worldwide technical generation potential, it can be seen that the latter is over four times greater than the former, indicating a positive outlook for hydropower growth. In 2010, the International Renewable Energy Agency (IRENA), estimated that the worldwide hydropower installed capacity was $936 \mathrm{GW}$ [35] (refer to Table 5), almost similar with the estimation done by the IEA in 2009.

The top ten hydropower producing countries as of 2010 are listed in Table 5 together with their installed capacity. From Table 5, it can be seen that some of the developed and emerging countries, namely, Norway, Canada, Sweden, and Brazil rely heavily on hydropower for their electricity generation. The IPCC states that the main reason for these developed countries to heavily invest in hydropower energy systems is to consolidate their electricity supply base so as to ensure energy security and trade [4]. The overdependence of hydropower for electricity generation in these nations demonstrates the capacity of renewable energy (hydropower) to be used for large scale industrial applications and for energy security. This observation also highlights the fact that hydropower is a mature and proven technology.

Also worth noting from Table 5 is that China and USA; despite being on the first and third positions in the list 
TABLE 5: Top ten countries by installed hydropower capacity and generation share in 2010, adapted from International Renewable Energy Agency [35].

\begin{tabular}{lccc}
\hline Country & $\begin{array}{c}\text { Installed } \\
\text { capacity }(\mathrm{GW})\end{array}$ & Country & $\begin{array}{c}\text { Hydropower } \\
\text { share of the total } \\
\text { generation }(\%)\end{array}$ \\
\hline China & 210 & Norway & 99 \\
Brazil & 84 & Brazil & 84 \\
USA & 79 & Venezuela & 74 \\
Canada & 74 & Canada & 59 \\
Russia & 50 & Sweden & 49 \\
India & 38 & Russia & 19 \\
Norway & 30 & India & 18 \\
Japan & 28 & China & 16 \\
France & 21 & Italy & 14 \\
Italy & 20 & France & 8 \\
Rest of the world & 302 & Rest of the world & 14 \\
World & 936 & World & 16 \\
\hline
\end{tabular}

of countries with largest hydropower installed capacity, hydropower does not even contribute up to $10 \%$ of its national generating capacity. In Africa, despite having small levels of installed capacity, most countries in the region have hydropower in their electricity generation mix. In 2008, hydropower accounted for about $70 \%$ of the total electricity generated in the sub-Saharan African region, excluding South Africa [51]. In 2010, 32\% of the African's electricity generation capacity was supplied from hydropower [52].

2.4. Environmental and Social Aspects of Hydropower. The major concern for the implementation hydropower projects is the environmental and social impacts associated with such projects, especially the large-scale ones. Before the actual hydropower project construction and plant installation, the impacts must be identified and detailed properly through separate studies. This is done during the environmental and social impact assessment stage and may take significant amount of project's time and resources, depending on site characteristics and project size $[53,54]$. The environmental and social assessment study must also come up with impacts mitigation measures. In extreme cases, where the impact mitigation measures and costs are prohibitive, the projects can be called off.

For a hydropower project, social and environmental impacts occur during construction and operation phases of the project. The construction phase of a large scale hydropower project involves putting up engineering structures such as roads, dam, weirs, tunnels, power plants structures, and electricity transmission lines. Land is cleared and some human settlements displaced to make room for such constructions. Inundation of land by the reservoir may destroy ecosystem, destroy infrastructure, and displace settlements. These activities result in localised air and water pollution, loss in biodiversity, destruction of infrastructure, change of landscape, destruction of settlements, and loss of livelihood and cultural identity in the direct project affected areas. Further, economic, social, and cultural challenges as a result of creation of "boom" town in the project area are some of the impacts of a large-scale hydropower project.

During the operation phase of the hydropower project, some sections of the river experience varied hydrologically. In run-of-river projects, part of the main river between flow diversion point and tailrace experiences low flow during operation. In storage hydropower system, part of the river downstream of the dam again experiences low flow condition. If the hydropower plant is used for peaking purposes, the downstream part of the river experiences flow fluctuations. The changes in the hydrology of the river (low flow and flow fluctuations) affect not only the aquatic ecosystem but also the local inhabitants who depend on riverine resources for their social-cultural and economic activities.

It is mandatory to preserve aquatic life. Provisions must be put in place to preserve biodiversity in the project impact area as well as to manage the welfare of project affected people. It is for these reasons that a developer of the hydropower project is obliged to come up with impacts of the mitigation program in the environmental and social assessment report. One of the compulsory mitigation measures is that the lowflow zone of the river must not be deprived of water below the acceptable environmental flow. Minimum environmental flow may be found from responsible national departments such as water and environments or from the international guidelines formulated by international financing institutions (e.g., the World Bank). The project affected people must be compensated or resettled or assisted in a special way so that they can at least afford to live a better life than that before the project. The involuntary resettlement of the displaced communities is stated to be one of the most difficult impacts to manage in the hydropower projects [55]. Large scale hydropower investments have become sensitive and the concerns have shifted from physical (e.g., dam safety) to environmental and social dimensions [55].

Large-scale hydropower projects seem to have unique characteristics that set them apart from other infrastructure projects in terms of emphasis on mitigation of environmental and social impacts. These characteristics may include the following: (i) the relatively huge magnitude of the hydropower physical structure itself, (ii) the project is located in rural setting where the impact on environment is likely to be huge due to the possibility that the local environment in the proposed project area may still be undisturbed and possibility that vulnerable communities and endangered species may be located in the proposed project area, and (iii) the perceived fact that the benefits from the hydropower electricity projects are "enjoyed and controlled" by urban populations and thus the rural population need to be protected against "exploitation." Apart from this, some international financing institutions have their own conditions (and areas of interest) on the environmental and impact assessment study which must be fulfilled before they can let out their finances for the hydropower project. Therefore, environment and social assessment studies for large-scale hydropower projects are involving and can be quite sensitive.

On the side of environmental and social impacts, smallscale hydropower systems look attractive, generally on the 
saying that "small is beautiful." A small-scale project has fewer environmental and social impacts, but it generates less electricity. Therefore, it might be important to find out how the total environmental impacts of a hydropower system comprising of several small scale units that are installed along a hydropower potential site compare with impacts arising from a single large scale hydropower plant installed on a similar potential site generating the same amount of electricity. In this case, then the environmental benefits are compared objectively, per unit of electricity generated. However, for the fact that small-scale hydropower projects are not associated with resettlement, socially, they are more acceptable than large-scale hydropower projects.

2.5. Hydropower and Climate Change. As it has been discussed already, hydropower, being a renewable energy, is among technologies that are known to produce electricity with least impacts on global climate change. However, large scale storage hydropower stations have been known to emit some greenhouse gases (GHGs), especially methane $\left(\mathrm{CH}_{4}\right)$ and carbon dioxide $\left(\mathrm{CO}_{2}\right)$ as a result of the buried organic matter decomposition in the absence of enough oxygen [56]. Because methane is the predominant gas in the total hydropower gaseous emission, contribution GHG of hydropower reservoirs is currently being encouraged not to be overlooked during the GHG national inventory exercises. Methane has more global warming potential than carbon dioxide. Intergovernmental Panel on Climate Change (IPCC) in its Fourth Assessment Report (Working Group I) estimated that methane is more than 21 times more global warming potential than carbon dioxide [11]. Other scientists argue that the global warming potential of methane is actually more than the IPCC value for a time horizon of 100 years [57].

In a hydropower project, the GHG gases in the reservoirs may escape to the atmosphere through surface bubbling in the reservoirs $[58,59]$. They may also escape during the process of turbulent degassing of dissolved gases in the water as water flows through the turbine runner during operation $[60,61]$. The deep water layers in the reservoir are usually rich in $\mathrm{CO}_{2}$ and $\mathrm{CH}_{4}$ concentration due to high mineralization rates and high water pressure (which give high gas solubility level). By passing through the turbines, the gases are exposed to low pressure and high temperature conditions and, together with turbulent action, rapid degassing and emissions to the atmosphere occur [60]. For this reason, water flow to generate energy in the turbine must not be obtained from deep water levels or lower parts of the reservoir. Despite the GHG emissions at the turbines, some relatively significant amounts of $\mathrm{CO}_{2}$ and $\mathrm{CH}_{4}$ may still remain dissolved in the water and may be degassed further in the course of flow after the turbine. GHGs produced in some reservoirs haven been encountered at locations far downstream of the reservoirs [62]. Reservoirs in tropical environments have been found to have significant amounts of GHG emission levels than reservoirs located in temperate climatic zones [63]. One possible reason for this is the relatively high values of water temperature in tropical climates which increase the rate of anaerobic organic matter decomposition in the reservoirs [59].

Compared to other electricity generation technologies, levels of GHG emission from hydropower are relatively low. The life cycle GHG emission factors for hydropower technologies are around $15-25 \mathrm{~g} \mathrm{CO}_{2}$ equivalent per $\mathrm{kWh}_{\mathrm{el}}$. These are very much less than those of fossil-fuel power generation technologies which typically range between 600 $1200 \mathrm{~g} \mathrm{CO}_{2}$ equivalent per $\mathrm{kWh}_{\mathrm{el}}$ [64]. Studies on life cycle GHG emissions from hydropower electricity technologies have been shown to possess large variations (varying from 0.2 to $152 \mathrm{~g} \mathrm{CO}_{2}$-equivalents per $\mathrm{kWh}_{\mathrm{el}}$ ) possibly due to the manufacturing process, type and nature of the reservoir (for hydropower) [65]. Even if the maximum value of GHG emission is considered, emissions from hydropower are very much less than those from fossil fuels. This shows the importance of hydropower in mitigating climate change.

2.6. Impacts of Environment and Climate Change in Hydropower Generation. As discussed already, hydropower projects can have impacts on the environment; however, the reverse is also true: the environment can also impart negative consequences on hydropower generation. As it has already been stated, environmental degradation is one of the major challenges facing the world in this century. It can be argued that this is due to the fact that every component of an economic system, such as agriculture, power generation, mining, and tourism, operates within a total environmental system and, thus, has the potential to disturb the environment. A large share of the level of the environmental degradation is human induced arising from unsustainable economic development practices and increase in population.

For a hydropower project, the quality and quantity of fresh water to generate power are sensitive to the environment and weather in the catchment area. In many cases, environmental degradation in the catchment area comes largely as a result of unsustainable agricultural practices and the use of inorganic fertiliser and unsustainable harvesting of forests. Sedimentation and aquatic weed infestation of reservoirs and rivers are some of the major problems facing hydropower generation as a result of environmental degradation.

Hydropower resource potential is sensitive to climate change because of its dependence on run-off water, a resource which is dependent on climate-driven hydrology (refer to Figure 2). Run-off depends on meteorological parameters such as precipitation and temperature. With global warming, the levels and duration of precipitation are affected. Further, the increase in global temperature has an effect in water loss through evaporation as well as snow and glacier melting. These climatic consequences may be global, regional, or local.

Various studies have been conducted on future impacts of climate change on hydropower generation potential, focussing on changes in run-off. Studies using the global circulation reveal that, in future, some regions of the world will experience increased run-off while others reduced runoff as a result of global warming [66-68]. Northern and 
Central America regions are expected to experience reduced hydropower generation potential while most of Europe is projected to have increased generation potential with some areas having reductions. In Australia, reductions are generally projected while New Zealand is projected to have increased generation potential. South America is projected to experience reduced hydropower production. Much of Southern and West Africa will have a reduction while East Africa is projected to have increased generation potential. For Asia, most countries have positive trends indicating an increase in hydropower potential; an exception is the Middle East which has decreasing trends. On global level, these studies are in agreement with the fact that global hydropower generation potential is predicted to increase, but very little (less than 1\% according to Hamududu and Killingtveit study [68]). Therefore, it can be seen from these studies that even if individual countries and regions will experience significant changes in run-off, climate change may not lead to significant changes in the global hydropower generation potential.

The studies on impacts of climate change on hydropower generation at national level present an opportunity to anticipate the degree of variation; hence climate related risks of developing a hydropower project in a specific country. However, most of the studies use global circulation model, which are less reliable despite being able to downscale the modeling to national levels. On top of generating varying climate change projections, they are also not efficient enough to describe the actual physical description of the national (or local) climate system. If the global circulation models are used in hydropower planning, the modeling results should be treated with care. In such cases, it is recommended to use many models so as to increase the level of reliability of the projections and therefore, to reduce levels of uncertainties. For example, in the case of Hamududu and Killingtveit [68] study, they had to use 12 different models and only if 6 or more of them agreed on the general trend of future runoff projections (increase, decrease, or unchanged), then a decision was made and a mean trend-line developed and the mean change calculated. Otherwise, the researchers were not able to make a decision about that nation with less than 6 models agreeing on the trends of run-off the projections.

Furthermore, regardless of whether an increase or decrease in run-off is encountered, in future, there are likely to be impacts on the system operation which may require adaptation measures if the existing hydropower systems are to cope with the climatic changes, considering the long life span of most large-scale hydropower projects [69]. Already, extreme weather events like droughts, floods, and hailstorms impact negatively on the hydropower generation by affecting water quantity and quality as well as destroying hydropower plant infrastructure. Increased frequency and magnitude of such extreme weather events are linked to being some of the impacts of climate change $[11,70]$. These events not only limit hydropower generation, but also increase the operational costs of the power system. Negative impacts of the events on hydropower generation are already felt in many countries like Malawi [43], India [71], Costa Lica [72], and Sri Lanka [73].
Iimi [70] argues that environmental risks such as sedimentation and flooding will likely increase due to changes in local hydrology as a result of the climate-related extreme weather events. This argument can be supported by the fact that with the local environment being degraded, the ability to cope with impacts of climate change is weakened. The impacts of such extreme weather events on hydropower generation can be extremely high making the hydropower systems in such locations very vulnerable. Furthermore, as a result of increased frequency and magnitude of droughts, competition for water resources in water-stress areas increases. Therefore, legal and illegal water abstractions from rivers and reservoirs increase and this situation limits water available for power production further.

In such situations of climate change impacts, adaptation measures such as using incremental hydropower generation to make effective use of increased run-off and to improve the performance of the generating unit by making sure that the available reduced flow supply the required design flow to particular turbine units. This adaptation measure will therefore, require use of several small-scale generating units instead of one large-scale generating unit. The other adaptation measures include employing turbine technologies that can optimally be operated in a variable flow environment, and also in a poor water quality environment. Climate change technical adaptation measures, such as flood attenuation and sediment extraction designs, must be integrated in the design of hydropower hydraulic structures like dams, barrages, weirs, settling basins, and channels.

\section{Conclusion}

The global energy sector overrelies on fossil fuel and is responsible for most of global environmental degradation and climate change. The global demand for energy supply is increasing and the supply is not sustainable. In the paper, it has been argued that fossil fuel proven reserves especially coal, are still able to support the current rate of energy production for the next several years. Therefore, fuel substitution to clean energy sources, such as renewable energy, is required. Fuel substitution is the major way to mitigate problems associated with fossil fuel supply. Hydropower has been reviewed as the most feasible source of renewable energy to provide significant levels of global energy, especially electricity. This paper has shown that though hydropower contributes a less share towards global primary energy supply, the hydropower undeveloped potential worldwide is relatively large. The fact that most of undeveloped potential is located in regions where electricity is needed most, such as in Africa, makes development of hydropower for sustainable energy supply in those regions relevant.

Hydropower is one of the most efficient power generation technologies. It is used in many countries and the paper has shown that some developed countries solely rely on hydropower for power supply. Therefore, the technology is mature and reliable as well. Hydropower technology can also be part of an integral energy system performing a role as an energy storage device. Hydropower storage system makes it possible for a power utility to store energy and use 
other energy sources with variable potential such as wind to supply an almost constant load. Some of the drawbacks for hydropower project are the relatively high investment costs and the risks associated. Economically, small-scale hydropower technology is suitable for private investments operating as independent power producers. Considering the financial constraints in many developing countries for large scale hydropower projects, small-scale projects may be one of the solutions to the small development of hydropower in such countries. Further, small-scale hydropower technology has the advantage of being applied as a standalone energy system for rural power supply. Therefore, hydropower can significantly contribute towards increased national energy access and security, mitigation of climate change and reduction of harmful air pollutants, creation of economic opportunities, and, thus, effectively leading to sustainable development.

The paper has also discussed the impacts of hydropower production on the local environment. It can be concluded that hydropower technology is one the most environmental and social sensitive power generation technologies. Though the impacts of hydropower projects depend on the size and the site, in general large-scale hydropower projects have greater impacts that small-scale projects. Hydropower projects are also highly susceptible to risks concerning environmental degradation and climate change. The occurrences of extreme weather events, which are exacerbated by climate change, have negatively impacted hydropower generation in some countries. Thus, careful planning and design are required so as to come up with sustainable hydropower projects.

Climate change is real and total environmental degradation in the catchment area is unavoidable. Though, on global basis, hydropower potential is projected to increase slightly with global warming, on country level, the situation is projected to be different from one country to the other. Some countries will experience increases in potential while others decreases, but with a great degree of risks in both cases. Therefore, hydropower designs should incorporate adaptation measures. This is an area which should be exploited by further research. Some measures of adaptation concerning variable flow turbine design, incremental power generation, and flood attenuation designs have been stated in the paper. Synergies concerning clean power production and climate change response offered by hydropower project must also be exploited. For example, apart from hydropower generation, reservoirs can also be used to control floods (one of the climate change adaptation measures).

\section{References}

[1] A. Bauen, "Future energy sources and systems-acting on climate change and energy security," Journal of Power Sources, vol. 157, no. 2, pp. 893-901, 2006.

[2] V. Gorshkov and A. Makarieva, Knowledge of the Environment. Quality of Human Resources Volume 1, UNESCO Encyclopaedia of Life Support Systems, 2005.
[3] International Energy Agency, "2011 key world energy statistics," IEA Report, The Economic Co-Operation and Development (OECD), 2012.

[4] Intergovernmental Panel on Climate Change, "Special report on renewable energy sources and climate change mitigation, chapter 5: hydropower," Special Report of IPCC, Cambridge University Printing Press, 2012.

[5] British Petroleum, "Statistical review of world energy," BP Report, British Petroleum, London, UK, 2012.

[6] InterAcademy Council, Lighting the Way: Toward a Sustainable Energy Future Report, Energy Supply, Chapter 3, The InterAcademy Council, The Netherlands, 2007.

[7] V. Modi, S. McDade, D. Lallement, and J. Saghir, Energy and the Millennium Development Goals, The Energy Sector Management Assistance Programme, United Nations Development Programme, UN Millennium Project, and World Bank, New York, NY, USA, 2006.

[8] E. Tsimas, A. Georgakaki, and S. Peteves, "Future fossil fuel electricity generation in Europe: options and consequences," Reference Report JRC, 42187, The Joint Research Centre (JRC) of the European Commission, The Netherlands, 2009.

[9] M. Tolba, The World Environment 1972-1992: Two Decades of Challenge, Chapman and Hall for UNEP, Nairobi, Kenya.

[10] W. Lutz, W. Sandersen, M. Baker, J. Carter, and C. Wood, The End of World Population Growth: Human Capital and Sustainable Development in the 21st Century, Earthscan, London, UK, 1st edition, 2004.

[11] Intergovernmental Panel on Climate Change, Climate Change: Working Group 1-The Physical Science Basis, Cambridge University Press, Cambridge, UK, 2007.

[12] Intergovernmental Panel on Climate Change, "Third assessment report, scientific basis: definitions (Appendix)," IPCC Report, 2001.

[13] United Nations Framework Convention on Climate Change (UNFCCC), UNFCCC Background, UNFCCC Information, http://unfccc.int/essential_background/items/6031.php, 2012.

[14] Young Europeans Discuss Sustainable Development (ENSAA), Defining Climate Change, ENSAA Information, 2012.

[15] United States Environmental Protection Agency (USEPA), Greenhouse Gas Overview, United States Environmental Protection Agency, Washington, DC, USA, 2012.

[16] Intergovernmental Panel on Climate Change, Intergovernmental Panel on Climate Change Fourth Assessment Report by Working Group III, Mitigation of Climate Change: Greenhouse Gas Emission Trends, IPCC Reports, 2007.

[17] J. Olivier, G. Janssens-Maenhout, and J. Peters, "Trends in global $\mathrm{CO}_{2}$ emissions 2012 report," Tech. Rep. 500114022, PBL Netherlands Environmental Assessment Agency.

[18] T. Morrigan, Target Atmospheric Greenhouse Gas Concentration: Why Should Humanity Aim For $350 \mathrm{Ppm} \mathrm{CO}_{2}$ eq? University of California, Global and International Studies Department, 2010.

[19] J. Ebinger and W. Vergara, Climate Impacts on Energy Systems: Key Issues for Energy Sector Adaptation, Energy Sector Management Assistant Program (ESMAP) of the World Bank, 2011.

[20] S. Teske, T. Pregger, S. Simon, T. Naegler, W. Graus, and C. Lins, "Energy revolution 2010 — a sustainable world energy outlook," Journal of Energy Efficiency, vol. 4, no. 3, pp. 409433, 2010 .

[21] M. Walton and L. Hendrix, The Promise of Renewables: Recent Success and Challenges of Getting to Scale-Commentary, The Geopolitics of Cleaner Energy, Centre for Strategic and International Studies, Washington DC, USA, 2012. 
[22] C. Kaunda, C. Kimambo, and T. Nielsen, "Potential of smallscale hydropower for electricity generation in Sub-Saharan Africa," ISRN Renewable Energy, vol. 2012, Article ID 132606, 15 pages, 2012.

[23] World Energy Council, Survey of Energy Resources: Hydropower, Country Reports, World Energy Council, London, UK, 2007.

[24] L. Jinghe, "Status and prospects of the small-scale hydro technologies in China," in Proceedings of the China Renewable Energy Development Strategy Workshop, p. 95, Tsinghua University, Beijing, China, October 2005.

[25] S. Majumdar, The Current Scenario of Developments in Renewable Energy in India: Hydro Energy Report, Renewable Energy \& Energy Efficiency Partnerships (REEEP), 2008.

[26] L. Kosnik, "The potential for small scale hydropower development in the US," Energy Policy, vol. 38, no. 10, pp. 5512-5519, 2010.

[27] Norwegian Ministry of Petroleum and Energy, "Facts 2008: energy and water resources in Norway," Norwegian Government Report.

[28] C. Penche, "Guide on how to develop a small hydropower plant," Technical Manual, European Small Hydropower Association, Brussels, Belgium, 2004.

[29] South African Department of Minerals and Energy, "Baseline study: hydropower in South Africa, department of minerals and energy, capacity building in energy efficiency and renewable energy," Tech. Rep. 2. 3. 4-19, Department of Minerals and Energy, Bangui, South Africa, 2004.

[30] International Energy Agency, Renewable Energy Essentials: Hydropower, International Energy Agency, 2010.

[31] World Commission for dams and W. Klunne, "Sustainable development of village level hydropower in Eastern and Southern Africa," in Proceedings of the 3rd Biannual Conference on Science Real and Relevant, p. 4, International Convention Centre (CSIR), Pretoria, South Africa, 2010.

[32] International Energy Agency, Hydropower and the Environment: Present Context and Guidelines for Future Action, Subtask 5 Main IEA Report, Volume 2, International Energy Agency, Amsterdam, The Netherlands, 2000.

[33] USA Department of Energy, Hydropower Technology Information. Basic Energy Information, http://wwwl.eere.energy .gov/water/hydro_plant_types.html, 2012.

[34] A. Brown, S. Muller, and Z. Dobrotkova, "Renewable energy markets and prospects by technology," International Energy Agency (IEA) Information Paper, International Energy Agency (IEA), Paris, France.

[35] International Renewable Energy Agency (IRENA), "Renewable energy technologies_cost analysis series, volume 1: power sector," IRENA Working Paper 3/5, 2012.

[36] H. Locker, Environmental Issues and Management for Hydropower Peaking Operations, United Nations, Department of Economic and Social Affairs (UN-ESA), 2004.

[37] E. Roth, "Why thermal power plants have relatively low efficiency," Sustainable Energy for All (SEAL) Paper, February 2005 Issue, 8 pages, Leonardo ENERGY, https://docs.google .com/file/d/0BzBU0gQlsdocYmI1NDkyMDctY2RmYy00YzY0LTgwYmYtY2RjZGFhN2U1ZDk2/edit?hl=en_GB\&pli=1.

[38] B. Haya, P. McCully, and B. Pearson, Damming the CDM: Why Big Hydro Is Ruiningthe Clean Development MechanIsm, International Rivers Network and Clean Develeopment Mechanism Watch, 2010.

[39] R. Venkateswaran, "Small hydro potential in India," in Proceedings of the International Conference on Association for Small Hydropower, Hangzhou, China, June 2007.
[40] H. Raghunath, Hydrology: Principles, Analysis and Design, New Age International, New Delhi, India, 2nd edition, 2009.

[41] J. Perez-Diaz, J. Sarasua, J. Fraile-Ardanuy, J. Wilhelmi, and J. Sanchez, "A control system for low-head diversion run-ofriver small hydro plants with pressure conduits considering the tailwater level variation," in Proceedings of the International Conference on Renewable Energies and Power Quality (ICREPQ '10), Granada, Spain, March 2010.

[42] T. Douglas, 'Green' Hydro Power: Understanding Impacts, Approvals, and Sustainability of Run-of-River Independent Power Projects in British Columbia, Watershed Watch Salmon Society, 2007.

[43] M. Gondwe, "Aspects of climate change: impacts on generation-the case of Malawi's Runof-River hydropower schemes," in Proceedings of the 6th International Conference on Hydropower (Hydropower '10), International Centre for Hydropower (ICH), Tromsø, Norway, February 2010.

[44] Y. Gogus, "Pumped water energy storage," in Energy Storage Systems, vol. 1, pp. 281-301, Encyclopedia of Life Support Systems, 2011.

[45] B. Brook, Pumped Hydro Energy Storage—Cost Estimates for a Feasible System, BravenewClimate, Adelaide, Australia, 2010.

[46] M. R. Mohan, S. R. Paranjothi, and S. Prince Israel, "Use of pumped-hydro as peak-load management plant in optimal scheduling of power systems," Electric Machines and Power Systems, vol. 25, no. 10, pp. 1047-1061, 1996.

[47] World Energy Council, Survey of Energy Resources: Hydropower, World Energy Council, 2010.

[48] Alternative Energy Primer, "Hydropower originates from the sun," http://www.alternativeenergyprimer.com/Hydropower .html, 2012.

[49] International Journal of Hydropower and Dams, World Hydropower Atlas \& Industry Guide, International Journal of Hydropower and Dams, Wallington, UK, 2010.

[50] International Hydropower Association (IHA), IHA, 2010 Activity Report, IHA, London, UK, 2010.

[51] A. Eberhard, V. Foster, C. Briceno-Garmendia, F. Ouedraogo, D. Camos, and M. Shkaratan, Underpowered: The State of the Power Sector in Sub-Saharan Africa, World Bank Document under the Africa Infrastructure Country Diagnostic ProjectSummary of Background Paper 6, http://www.infrastructureafrica.org/system/files/BP6_Power_sector_maintxt.pdf.

[52] International Hydropower Association (IHA), IHA, 2011 ActivityReport, International Hydropower Association, London, UK, 2011.

[53] D. Egré and J. C. Milewski, "The diversity of hydropower projects," Energy Policy, vol. 30, no. 14, pp. 1225-1230, 2002.

[54] R. Sternberg, "Hydropower: dimensions of social and environmental coexistence," Renewable and Sustainable Energy Reviews, vol. 12, no. 6, pp. 1588-1621, 2008.

[55] M. Cernea, "Hydropower dams and social impacts: a sociological perspective," Social Development Papers, World Bank Paper 16, 1997.

[56] R. Howarth, R. Santoro, and A. Ingraffea, "Methane and the greenhouse-gas footprint of natural gas from shale formations," Journal of Climatic Change, vol. 106, no. 4, pp. 679-690, 2011.

[57] B. Dessus and B. Laponche, "Reducing methane emissions: the other climate change challenge," Working Paper 68, Agence Française de Développement, Paris, France, 2008.

[58] P. Fearnside, "Greenhouse gas emissions from a hydroelectric reservoir (Brazil's Tucurui dam) and the energy policy implications," Journal of Water, Air and Soil Pollution, vol. 133, no. 1-4, pp. 69-96, 2002. 
[59] V. L. S. Louis, C. A. Kelly, E. Duchemin, J. W. M. Rudd, and D. M. Rosenberg, "Reservoir surfaces as sources of greenhouse gases to the atmosphere: a global estimate," BioScience, vol. 50, no. 9, pp. 766-775, 2000.

[60] A. Kemenes, B. Forsberg, and J. Melack, "Methane release below a tropical hydroelectric dam," Geophysical Research Letters, vol. 34, article L12809, 2007.

[61] P. M. Fearnside, "Greenhouse gas emissions from hydroelectric dams: controversies provide a springboard for rethinking a supposedly "clean" energy source. An editorial comment," Climatic Change, vol. 66, no. 1-2, pp. 1-8, 2004.

[62] F. Guerin, G. Abril, S. Richard et al., "Methane and carbon dioxide emissions from tropical reservoirs: significance of downstream rivers," Geophysical Research Letters, vol. 33, article L21407, 2006.

[63] L. P. Rosa, M. A. dos Santos, B. Matvienko, E. O. dos Santos, and E. Sikar, "Greenhouse gas emissions from hydroelectric reservoirs in tropical regions," Climatic Change, vol. 66, no. 12, pp. 9-21, 2004.

[64] M. Lenzen, "Life cycle energy and greenhouse gas emissions of nuclear energy: a review," Energy Conversion and Management, vol. 49, no. 8, pp. 2178-2199, 2008.

[65] H. L. Raadal, L. Gagnon, I. S. Modahl, and O. J. Hanssen, "Life cycle greenhouse gas (GHG) emissions from the generation of wind and hydro power," Renewable and Sustainable Energy Reviews, vol. 15, no. 7, pp. 3417-3422, 2011.

[66] P. C. D. Milly, K. A. Dunne, and A. V. Vecchia, "Global pattern of trends in streamflow and water availability in a changing climate," Nature, vol. 438, no. 7066, pp. 347-350, 2005.

[67] B. Bates, Z. Kundzewicz, S. Wu, and J. Palutikof, "Climate change and water," Intergovernmental Panel on Climate Change (IPCC) Technical Paper, IPCC Secretariat, Geneva, Switzerland, 2008.

[68] B. Hamududu and A. Killingtveit, "Assessing cimate cange ipacts on gobal hydropower," Journal of Energies, vol. 5, pp. 305-322, 2012.

[69] O. Martin, L. Lillehammer, and O. Hveling, "Hydropower development and curbing climate gas emissions: a win-win opportunity," in Proceedings of the 6th International Conference on Hydropower (Hydropower '10), International Centre for Hydropower, Tromsø, Norway, February 2010.

[70] A. Iimi, "Estimating global climate change impacts on hydropower projects: applications in India, Sri Lanka and Vietnam," Policy Research Working Paper 4344, Sustainable Development Network, The World Bank, 2007.

[71] K. Nair, "An analysis of the issues associated with hydropower generation in Kerala-India, under changing climate," in Proceedings of the 6th International Conference on Hydropower (Hydropower '10), International Centre for Hydropower, Tromsø, Norway, February 2010.

[72] J. Aragon, "Vulnerability of hydroelectric plants in tropical Basins with high slope in Cost Lica," in Proceedings of the 6th International Conference on Hydropower (Hydropower '10), International Centre for Hydropower, Tromsø, Norway, February 2010.

[73] S. Elakanda, "Impacts of climate change on hydropower generation in Sri Lanka," in Proceedings of the 6th International Hydropower Conference on Hydropower (Hydropower '10), International Centre for Hydropower, Tromsø, Norway, February 2010. 

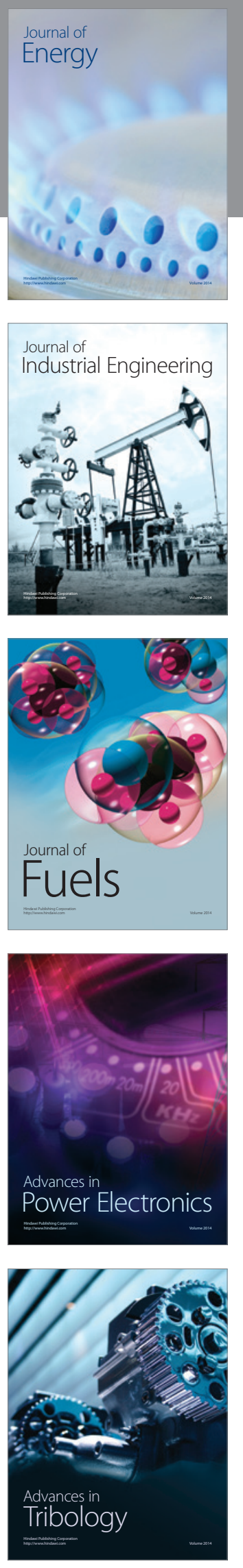
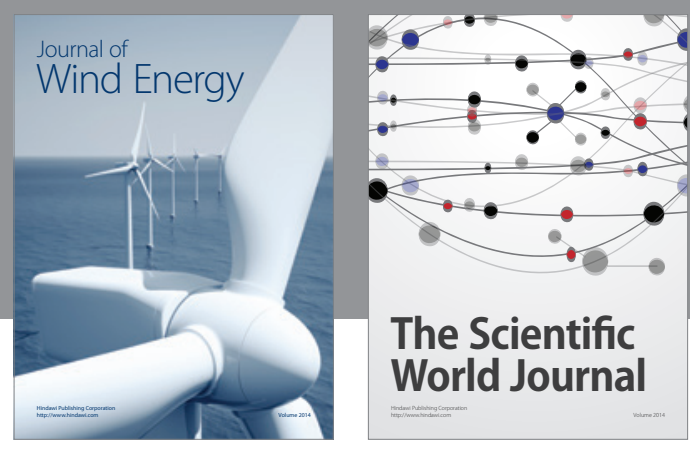

The Scientific World Journal

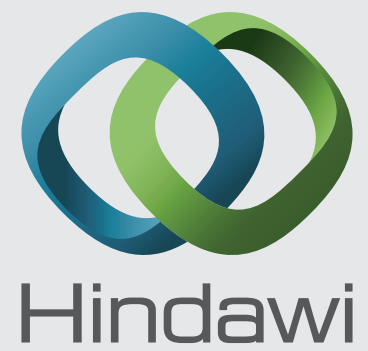

Submit your manuscripts at http://www.hindawi.com
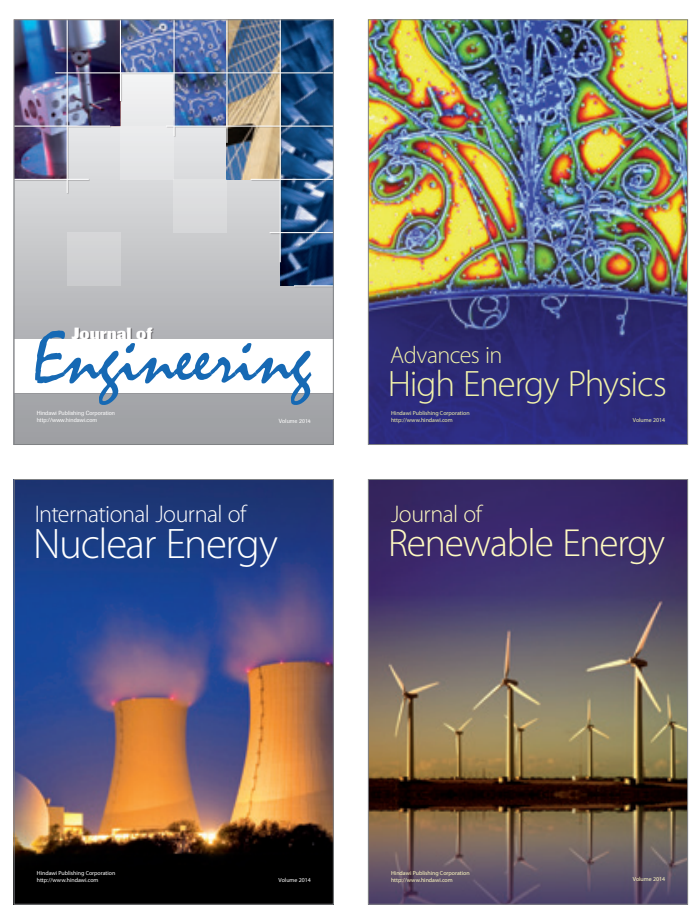

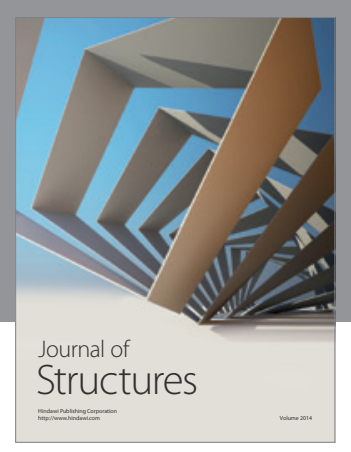

Rotating
Mechinery
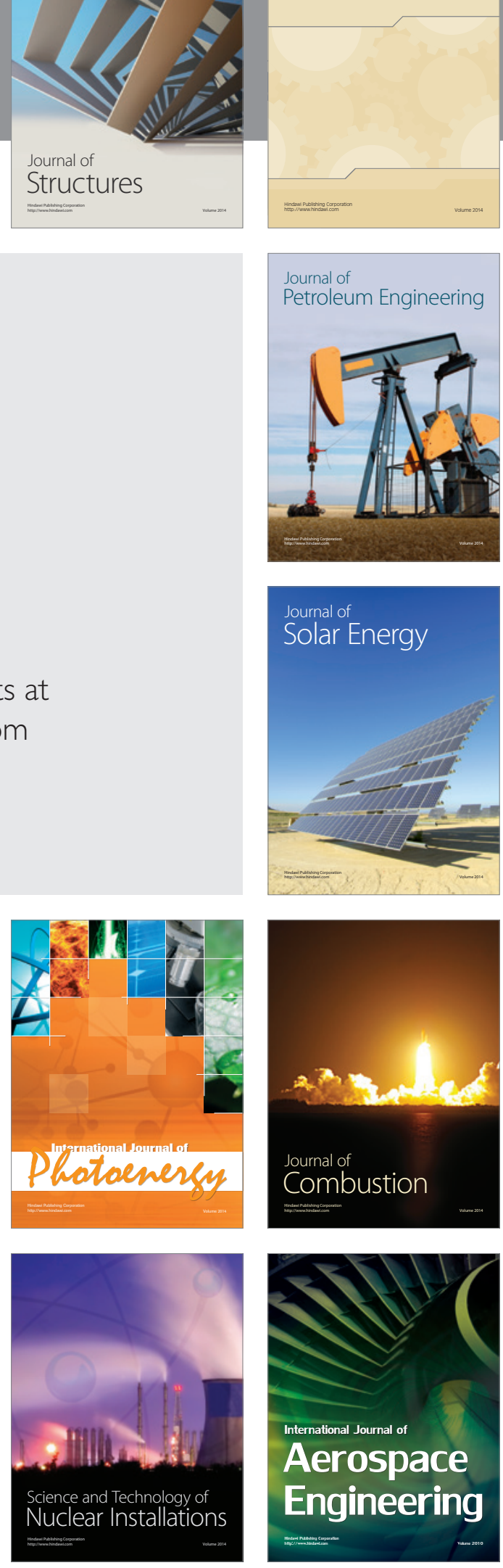